Critical Policy Studies

\title{
Paths are what actors make of them
}

\section{Zeki Sarigil}

To cite this article: Zeki Sarigil (2009) Paths are what actors make of them, Critical Policy Studies, 3:1, 121-140, DOI: 10.1080/19460170903158214

To link to this article: https://doi.org/10.1080/19460170903158214

央 Published online: 30 Nov 2009.

13 Submit your article to this journal $\pi$

LII Article views: 193

7 Citing articles: 7 View citing articles 


\title{
Paths are what actors make of them
}

\author{
Zeki Sarigil* \\ Department of Political Science, Bilkent University, 06800, Bilkent, Ankara, Turkey
}

\begin{abstract}
Several institutionalist orientations such as historical institutionalism, especially its earlier versions, tend to treat institutional or policy change as a result of exogenous factors. Some others, on the other hand, emphasize endogenous sources of change. It has, however, already been shown theoretically and empirically that institutions may face both endogenous and/or exogenous triggers in their lifetime. This study suggests that we should get beyond this fruitless debate and focus on the more intriguing question of why some internal or external triggers create major changes while others do not. This study suggests that some external or internal developments are more likely to trigger change than others because they carry with them certain meanings or ideas for change entrepreneurs. This implies that paying more attention to agency would significantly improve the historical institutionalist account of institutional or policy change. These arguments are illustrated by an analysis of recent institutional changes in the area of cultural rights in Turkey, i.e. in the Kurdish issue.
\end{abstract}

Keywords: path dependence; institutional change; change entrepreneurs; Turkey's Kurdish issue; cultural rights

One widespread criticism of new institutionalist approaches is that they pay a significant amount of attention to the impact of institutions on political outcomes, while paying scant attention to the origins of institutions and institutional changes (Thelen and Steinmo 1992, p. 15, Genschel 1997, p. 44, Colomy 1998, p. 266, Pierson 2000a, 2004, p. 103-45, Stacey and Rittberger 2003, p. 859, Sheingate 2003, p. 185, Thelen 2004, p. 25, Campbell 2004, p. 173, Harty 2005). These criticisms of relative inattention to institutional change have recently led to an increasing number of studies trying to theorize institutional change (see Campbell 2004, Greif and Laitin 2004, Thelen 2004, Streeck and Thelen 2005, Héritier 2007).

The failure of institutionalists to identify the source of instability, conflicts or institutional change is a direct result of a weak account of agency in several new institutionalist approaches (see Colomy 1998, Emirbayer and Mische 1998, Beckert 1999, Peters et al. 2005). This observation is also valid for historical intuitionalism (HI hereafter), which is better suited to explaining the persistence of patterns and continuities over time than to explaining shifts in those patterns (Thelen and Steinmo 1992, p. 15, Hall and Taylor 1996, p. 942, Hay and Wincott 1998, p. 955, Peters 1999, p. 68, Stacey and Rittberger 2003, p. 867, Campbell 2004, p. 68, Peters et al. 2005). As a remedy for this weakness, it is proposed that HI should employ a more dynamic notion of agency (Peters et al. 2005, p. 1277-85).

*Email: sarigil@bilkent.edu.tr 
The main focus of this study will be on an important aspect of institutional change, initiation, which remains a controversial matter in institutionalist studies. Several institutionalist orientations, in particular the earlier versions of HI, argue that some exogenous events or triggers initiate the transformative process. The critiques of these studies argue that such an approach relies on an exogenous deus ex machina to account for change (Crouch and Farrell 2004) and does not tell us much about the timing, direction and mechanisms of the change process (Legro 2000, p. 423, Campbell 2004, p. 5). Instead, they argue that institutional change might also originate endogenously. In response to these criticisms, recent historical institutionalist studies have paid more attention to endogenous developments as initiators of path-breaking changes (see Streeck and Thelen 2005).

Both approaches to the source of institutional change, however, suffer from selection bias due to their focus on either exogenous or endogenous developments or shocks leading to positive outcomes in terms of institutional or policy change. Negative cases, in which certain relevant external or internal developments (even at the level of a shock) exist, but do not create an institutional change, are usually excluded from the analysis. When we correct for this bias, we notice that institutions are more responsive to some developments than to others. The question then becomes: how can we explain this variance? This study suggests that we should concentrate our efforts on this puzzling situation. In other words, rather than losing time and energy in fruitless debates such as that on whether change originates endogenously or exogenously, we should focus on the following question: Why are certain endogenous or exogenous triggers more likely to initiate a structural change than some others?

Following the agential turn in the new institutionalist thought, this study argues that certain external or internal developments are more likely to initiate change than others because they carry with them certain meanings or ideas for institutional actors, especially for change entrepreneurs. As a result, change entrepreneurs become more responsive to those external or internal triggers and so mobilize to promote an institutional transformation. This, in return, increases the likelihood of a structural change. Thus, paying more attention to human agency would significantly improve the historical institutionalist account of institutional change. These arguments are illustrated by an analysis of recent institutional changes in the area of cultural rights in Turkey, i.e. in the Kurdish issue.

The design of this article is as follows. The theoretical part first briefly provides the main premises of the historical institutionalist account of institutional change and discusses some of its limitations. It then presents the definitions, arguments and hypothetical expectation relating to the initiation of change processes. The case study section explores the empirical plausibility of the theoretical arguments. This part first identifies the institutional path and its origins in Turkey's Kurdish issue. Then, it presents recent changes in the field of cultural rights. The case study section addresses the following questions: what do these changes mean (i.e. path-breaking or path following)? What was the main trigger for the change process? Why did these changes not take place at an earlier time? The concluding part restates the main arguments of the study and discusses some implications for theorizing institutional change.

\section{Part I: the historical institutionalist account of institutional change}

In order to have a better grasp of HI's position on institutional change, it would be helpful to have a brief look at the defining features of this theoretical orientation. The existing studies tend to link historical institutionalism to a path dependence approach (PDA) (Thelen and Steinmo 1992, p. 2, Blyth 2002, p. 19, Greener 2005, p. 63). The PDA simply 
claims that 'what happened at an earlier point in time will affect the possible outcomes of a sequence of events occurring at a later point in time' (Sewell 1996, pp. 262-3). In a similar fashion, Levi proposes that path dependence means that 'once a country or region has started down a track, the costs of reversal are very high. There will be other choice points, but the entrenchments of certain institutional arrangements obstruct an easy reversal of the initial choice' (1997, p. 28). Thus, this approach asserts that 'history matters' because 'where we go next depends not only on where we are now, but also upon where we have been' (Liebowitz and Margolis 1999, p. 981).

For the PDA, paths arise out of some contingent occurrences, either right at the beginning or at critical junctures that create a new path (Arthur 1994, pp. 37, 44-5, Pierson 2000b, p. 253, Mahoney 2000, p. 511, Gains et al. 2005, p. 28). Once created, institutional paths become inflexible in the sense that further steps make shifting from the existing path to another one very arduous (Pierson 2004, p. 157). In other words, once an institutional equilibrium is achieved, this equilibrium locks itself in.

With respect to 'change', the PDA tends to treat change as an incremental, evolutionary, path-following development (Levi 1990, p. 415, Hemerijck 1995, Genschel 1997, Mahoney 2001, Dimitrakopoulos 2001, Pierson 2004, p. 153). Substantial, revolutionary or path-breaking shifts happen at critical moments, or critical junctures, which are defined as 'choice points' for actors (Collier and Collier 1991, Mahoney 2001, p. 113). At these branching points, usually created by some externally driven developments like disturbances or shocks (Krasner 1984, Ikenberry 1989, Alexander 2001, p. 254, Schwartz 2005, p. 11-12), a new institutional path arises among several choices. ${ }^{1}$

Rooted in such an approach, HI considers 'change' as a sudden collapse of institutional equilibria, stability or patterns, usually caused by externally driven dramatic events such as wars, economic crises, dramatic technological developments, epidemics or natural disasters (see Hall and Taylor, 1996, Alexander 2001, p. 254, Schwartz 2005, p. 11-12, Harty 2005, p. 60, Greener 2005, p. 69). The infamous notion of 'punctuated equilibria' refers to such rapid deviations from the existing path (Krasner 1984, Baumgartner and Jones 1991). Otherwise, institutional change is expected to be incremental and path following (Powell 1991, p. 197, Hemerijck 1995, Dimitrakopoulos 2001). Thus, HI treats change as either very minor or very dramatic. Those dramatic or radical shifts (i.e. path-breaking changes), which are rare, take place after long periods of continuity (Pempel 1998).

Such an understanding (i.e. explaining change by exogenously induced variation) is widely shared in most accounts of institutional change in new institutionalism (Zucker 1988 , p. 25, Stacey and Rittberger 2003, p. 859, Sheingate 2003, p. 187). It is based on the idea that institutions have self-reinforcing features and changes in those self-enforcing structures should originate exogenously (Zucker 1988, p. 27, Blyth 2002, p. 20, Greif and Laitin 2004, p. 633).

Some other studies, on the other hand, suggest that the source of change might be also endogenous to institutions or sometimes both endogenous and exogenous (see Zucker 1988, p. 27-8, Sheingate 2003, Campbell 2004, p. 174, Greif and Laitin 2004, Schwartz 2005, p. 11-12, Streeck and Thelen 2005, Deeg 2005, Carter 2008, Olsen 2009, Williams 2009). For example, Streeck and Thelen (2005) indicate that 'institutional transformation' or 'path-breaking' change might be not only incremental or gradual but also endogenous.

\section{Moving beyond the exogeneity vs. endogeneity debate}

The initiation of change is an important phase of the whole process of institutional transformation and there is still a strong need for more theoretical efforts on this issue. 
We should, however, go beyond the debate of exogenous vs. endogenous - a debate which involves several problems. First of all, it assumes that institutional boundaries are clear. However, it is often the case in the institutional world that it is rather difficult to identify institutional boundaries. This is even more valid for complex systems in which there are 'multiple, overlapping, and heterogeneous components connected together in a dense network of interrelated links' (Sheingate 2003, p. 191). Given this, such a debate does not have much value. Secondly, even if we can identify institutional boundaries clearly, the line between exogeneity and endogeneity might still be indistinct. As Harty (2005, p.60) rightly states 'in some cases the line between exogeneity and endogeneity is in fact blurred. An exogenous shock might emerge in response to factors that are endogenous to an institutional system'. ${ }^{2}$

Thirdly, and most importantly, these arguments suffer from a methodological weakness, i.e. selection bias. We can illustrate this crucial point by analyzing the exogeneity approach. ${ }^{3}$ It is quite likely that, across space and time in the institutional world, a certain institution would encounter many exogenous developments, shocks or pressures which might be more or less equally likely to create a path-breaking change. However, we do not see that many path-breaking changes in the institutional world. The question, then, becomes why certain external factors (or internal ones) create change or instability in an institutional setting but others do not. For instance, in Figure 1, $E_{2}$ as an exogenous shock leads to a path-breaking change but other exogenous events $\left(E_{1}\right.$ and $\left.E_{3}\right)$ do not cause such a change. An historical institutionalist response to this question might be that a certain external event may lead to a path-breaking change while others do not because only that external event $\left(E_{2}\right)$ would create an exogenous shock strong enough to push the institution off its path. However, this kind of answer is far away from being satisfactory because it is simply non-falsifiable in the sense that if that is the case, then what is the necessary degree of shock or perturbation for path-breaking change to happen? Since it is not clear which events are of enough magnitude to create substantial policy changes, it becomes rather arduous to provide a definitive answer to such a question (see also Nohrstedt 2008, p. 258).

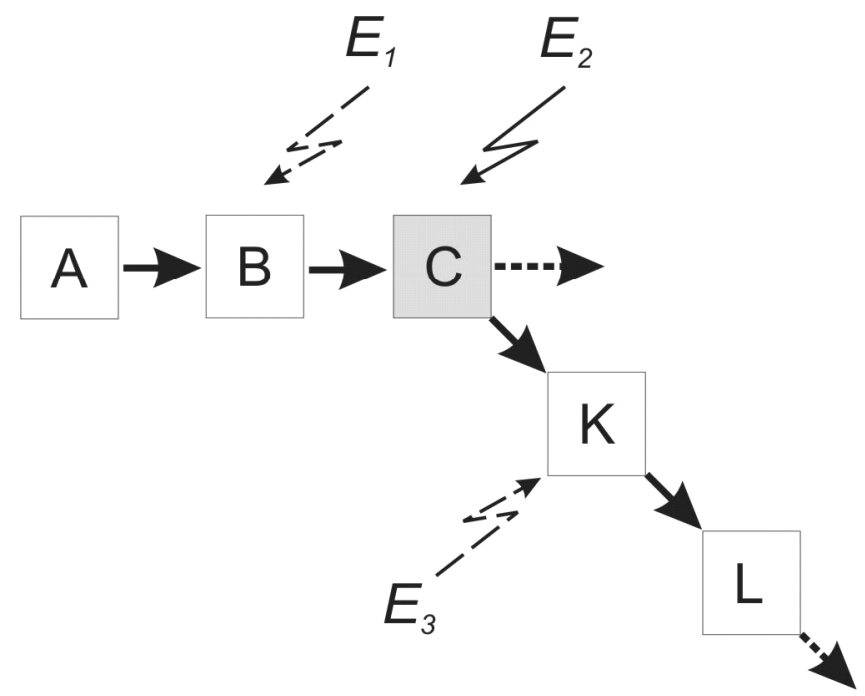

Figure 1. An illustration of exogenous shock and path-breaking change. (Adapted from Mahoney 2000). 
Institutional theories exogenizing the source of change remain limited in their capacity to addressing these difficulties because these approaches, as indicated before, focus on exogenous factors leading to positive outcomes in terms of institutional change. Negative cases, in which certain external developments - even at the level of shock - exist, but do not cause institutional change (such as $E_{1}$ and $E_{3}$ in Figure 1), are generally ignored. This is, therefore, a selection bias. This methodological problem, the exclusion of relevant negative cases, creates serious difficulties in terms of causal inference in any kind of study (see Mahoney and Goertz 2004).

To sum up, it has already been theoretically and empirically shown that institutions may face both endogenous and/or exogenous triggers in their lifetime. However, only some of these triggers result in institutional transformation (i.e. path-breaking change) (see also Nohrstedt 2008). The existing studies of institutional change tend to analyze the positive cases, while neglecting the negative ones (i.e. where there is no change despite the presence of external or internal triggers). If we pay more attention to the relevant negative cases, we realize that while institutional actors are quite responsive to some external events (or internal ones), they are less sensitive to others. This study, then, suggests that rather than participating in an idle debate as to whether the source of change is exogenous or endogenous, we should turn our attention to this puzzling variance. This work argues that explaining this variance requires paying much more attention to factors other than those triggers themselves. One of these factors should be the meanings of particular developments for the actors in a particular institutional environment.

\section{Definitions, arguments and the hypothetical expectation}

In this study, the concept of 'institution' refers to formal or informal social structures of norms, rules, and practices that regulate (constrain or enable) the course of actions among actors in a certain scope and domain (Helmke and Levitsky 2004, p. 727, Knight 1992, Carey 2000). One problematic tendency in new institutionalist thought is the assumption of a homogenous institutional environment. As Crouch and Keune (2005, p. 83) state 'neo-institutionalist analysis often starts from an assumption of homogeneity, that is, it depicts the institutions of a society as highly systematic, with everything operating according to a single logic, with endogenous actors operating within a single action space' (see also Powell 1991, p. 183, and Colomy 1998). This assumption, however, does not apply universally across the institutional world because institutional actors usually interact in a heterogeneous institutional environment with different logics of expectations and action, due to varied interests, beliefs and ideas. Thus, this study acknowledges the presence of a certain degree of heterogeneity in institutionalized settings, leading to a better understanding of institutional change. As Eisenstadt (1964, p. 246) convincingly states, 'any institutional system is never fully "homogenous", that is, fully accepted or accepted to the same degree by all those who participate in it, and these different orientations all may become foci of conflict and of potential institutional change' (see also Olsen 2009, p. 18).

Institutional heterogeneity is important for institutional stability because it creates distributional advantages and disadvantages among institutional actors (Knight 1992). These distributional outcomes, in return, create three types of clusters of actors in institutionalized settings: pro-status quo, pro-change and neutral actors. Pro-status quo actors are relatively satisfied with the existing institutional arrangements, while the neutral actors do not have clear preferences between either existing institutional configurations or possible alternative arrangements. Thus, they need to be convinced to change their understandings and preferences either in favor of change or of the status quo. Pro-change actors, or 
change entrepreneurs, on the other hand, are eager to redesign the institutional setting to advance their material and/or ideational/symbolic interests or concerns. They are 'creative and resourceful leaders', who always 'search for change, respond to it and exploit it as an opportunity' (Sheingate 2003, p. 188, Drucker in Dees 1998, p. 2).

Institutional change should be treated as a conflictual process which involves two main phases: initiation and bargaining. This study is primarily concerned with the first stage and tries to address the question of why some exogenous or endogenous developments are more likely to initiate change than others. We will provide a better answer to this question if we 'bring agency back in' (Homans 1964). Thus, this study borrows several theoretical elements from the policy entrepreneurship model (PEM), which emphasizes the role of policy entrepreneurs or change agents in institutional or policy shifts (see Mintrom and Vergari 1996, Mintrom 1997). As Mintrom and Vergari (1996, p. 423) indicate, change agents 'seek to sell their policy ideas and, in so doing, to promote dynamic policy change'. In order to promote their ideas and projects, they become involved in several activities such as 'identifying problems, shaping the terms of policy debates, crafting arguments, networking in policy circles and building coalitions'. For the purpose of forming a winning coalition, change agents frame the issue in a way designed to demonstrate to potential coalition members (e.g. neutral actors) how their interests will be advanced by joining it (Mintrom and Vergari 1996, p. 431). Thus, responding to certain internal and/or external developments or triggers, change entrepreneurs launch the transformative process by making creative destructions at the first stage.

Once the process is initiated, institutional actors start to bargain, either in a tacit or explicit manner over possible alternative arrangements at the second stage. The bargaining stage, however, has major implications for the initiation of the change process in the first stage, because change entrepreneurs are aware of the fact that during the following bargaining stage they will have to legitimate their projects to persuade the status-quo oriented actors of the necessity for change. This will be relatively easier if the external or internal trigger matches, at least to a certain degree, the broader institutional ideals and values. What this suggests is that change entrepreneurs are more likely to be mobilized by triggers resonating with the existing larger practices, shared ideals and worldviews, because such triggers will be relatively easy to frame and utilize in order to promote major policy changes in a specific policy area. In other words, the compatibility between the trigger and the larger institutional setting or environment becomes an asset for change agents in their efforts to sell their policy ideas in a specific area. Then, the real source of change becomes neither exogenous shocks nor endogenous developments, but lies with the interpretations, constructions and framings by change agents of those developments. Thus, we might expect that:

$H_{1}$ : In terms of the initiation of a change process in an issue or policy area, one trigger (endogenous or exogenous) is more likely to succeed than another if that trigger resonates, at least to a certain degree, with the broader institutional configuration.

By analyzing the recent changes in Turkey's Kurdish issue, the following section conducts a plausibility probe to illustrate these points.

\section{Part II: Case Study}

The Turkish Republic has been facing the Kurdish problem since its establishment in the early 1920s. In the last two or three decades, however, this problem has emerged as one of 
the major challenges to the Turkish state and democracy (Gunter 1997, p. 127, Özbudun 2000, p. 143, Kramer 2000, p. 52, Moustakis and Chaudhuri 2005, p. 78, Somer 2005b, p. 595). The origins of this problem date back to the rise of the Turkish Republic as a modern nation state from the remnants of the multi-ethnic, multi-religious and multilingual Ottoman Empire. Although the founders of the Republic desired to break completely from the Ottoman past, one can identify several continuities between these two political systems. Regarding our subject, the notion of 'minority' in the young Republic was quite similar to the 'millet system' which constituted the basis of Ottoman socio-political structure. Millets were religious communities in the Empire. The Empire recognized only non-Muslim religious communities such as Armenians, Greeks and Jews as minorities who were entitled to a certain degree of autonomy in taxation, education, religious practices and judicial proceedings (Braude and Lewis 1982, Oran 2000, p. 151, Somer 2005a, p. 79). On the other hand, all Muslim ethnic groups (e.g. Albanians, Arabs, Bosnians, Circassions, Kurds, Laz, Pomaks, Tatars and Turks) were defined as the constituents of Islam or Muslim millet and viewed as the subjects of the Caliph (also the Sultan), regardless of their ethnic or cultural differences (Kirişçi and Winrow 1997, p. 1, Oran 2000, p. 154).

Rather similarly, the Republic's notion of minority is shaped by religion rather than ethnicity or language. For the Treaty of Lausanne (24 July 1923), which marked the recognition of the Republic of Turkey in the world, the Turkish state only recognized nonMuslim citizens - Jews, Orthodox Greeks and Armenian Christians - as minorities and allowed them to have some special rights (Articles 37-45). Thus, although the Republic accepted the existence of religious minorities, ethnic minorities were not recognized (Kirişçi and Winrow 1997, p. 45). The ultimate purpose of the founders of the Republic was to establish a nationally homogenous, modern, secular and centralized nation state from the remnants of what had been a heterogeneous Empire (Göle 1997, Kasaba and Bozdoğan 2000, Gürbey 1996, p. 10, Kramer 2000, p. 9, Romano 2006, p. 118, Soner 2005). As a result, all Muslim ethnic groups were defined as the components of the 'Turkish nation'. Thus, the Republic expected Kurds to identify themselves as Turks (Kramer 2000, p. 40, Ergil 2000, p. 125).

Although the Kemalist leadership initially adopted a relatively more plural and liberal rhetoric, such as 'peoples of Turkey' or 'nation of Turkey', we can observe an increasing emphasis on 'Turkishness', or 'Turkish nation' since the mid-1920s. It has been suggested that, especially after the Kurdish-led Shaykh Said Rebellion (1925), which increased the fears of the disintegration of the newly established Republic (Kirişçi and Winrow 1997, p. 100, Watts 1999, p. 634, Oran 2000, p. 155), an extensive policy of assimilation, with a goal of Turkification of different Muslim ethnic groups (mainly the Kurds) was adopted (see Bruinessen 1978, p. 242, Gunter 1990, p. 44-57, Kymlicka 1995, p.132, Barkey 1996, p. 66, Kiriş̧i and Winrow 1997, p. 100, Barkey and Fuller 1997, p. 63, Watts 1999, p. 634, Ergil 2000, p. 125, Yavuz 2001, p. 4, Saatçi 2002, p. 557, Magen 2003, p. 16, Aydın and Keyman 2004, p. 34, Somer 2004 and 2005a, p. 81, Oran 2005, Romano 2006, pp. 24-117, Akyol 2006, pp. 76-103, Watts 2006, p. 128). As Romano (2006, p.120) states,

All things specifically Kurdish, be they language, cultural practices, names, history, or literature, were either excluded or taken over and determined to be actually Turkish in origin. Turkish academics produced studies that showed Kurdish to actually be a perverted dialect of Turkish rather than a distinct language, and even the term 'Kurd' became taboo in public discourse. ${ }^{4}$

In brief, the Turkish Republic emerged onto the world stage as a nationally homogenous, modern, secular and centralized nation state. Any ethnic, ideological, religious or 
economic differences between Muslim communities were viewed as a threat to the unity and progress of the Republic (Gunter 1990, p. 123, Gürbey 1996, p. 10, Göle 1997, p. 84). As a result, ethno-cultural distinctions among the Muslim population were ignored and any public expression of those differences or demands for cultural rights were suppressed. Since the Kurds constituted the second largest ethnic group after the Turks, the denial and suppression of ethnic identities other than the Turkish identity constituted a major problem for this group. This institutional path (i.e. the denial and suppression of Kurdish identity) maintained itself until the late 1990s. Since the early 2000s, however, the Republic has adopted major constitutional and legislative reforms which have brought significant changes on this important matter. The following section lays out some of the major changes in the area of cultural rights that took place in the early 2000s and then theorizes the initiation of this transformative process.

\section{Enhancing cultural rights}

In October 2001, the Turkish parliament passed a major constitutional package, which changed 34 articles of the current constitution. It was the most extensive amendment since the adoption of the constitution in 1982. With respect to cultural rights, the constitutional reform brought the following important changes: the third paragraph of Article 26, which stated 'No language prohibited by law shall be used in the expression and dissemination of thought', was removed. The second paragraph of Article 28, which ordered that 'Publication shall not be made in any language prohibited by law', was also abolished. As a result of these changes, restrictions on the use of Kurdish language in speech, publications and broadcasting was eased.

In the aftermath of these constitutional amendments, the Turkish parliament passed several Harmonizing Packages to make the existing laws compatible with the amended constitution and adopted new laws, bylaws and administrative ordinance. For instance, the Second Harmonizing Package (March 2002) eased language restrictions in the press. In August 2002, the Third Harmonizing Package, also known as the Mini-Democracy Package, brought substantial changes in Turkey. It is considered as the most significant harmonizing package among those passed by the Turkish parliament (Magen 2003, p. 19, Uğur 2003, p. 177, Aydın and Keyman 2004, p. 16). ${ }^{5}$ For some, this reform package 'began to dispose of the old taboos of Turkish political life' (Zucconi 2003, p. 30). This reform package legalized radio and television broadcasts (public and private) in languages and dialects other than Turkish (primarily Kurdish) and permitted the learning of those languages and dialects through private language courses, ending the existing state restrictions. Following these legal changes, the first private Kurdish courses commenced in Batman, Şanliurfa and Van in the southeastern Turkey. The state-run TV channel, the TRT, started broadcasting in Kurdish, Bosnian, Arabic and Circassion in June 2004, which had hitherto been seen as an 'unimaginable event' in Turkey (Akyol 2006, p. 15). ${ }^{6}$ The Fourth Harmonizing Package (January 2003) removed some language restrictions on the activities of associations and allowed the use of foreign languages in their non-official communications. The Sixth Harmonizing Package (July 2003) restated the granting of permission to private radios and TV channels to broadcast in the various languages and dialects which were used by Turkish citizens. In addition, this package permitted parents to name their children as they wish (i.e. Kurdish names could be chosen).

What do all these changes mean? Some studies suggest that these changes remain more cosmetic than real (Romano 2006, p. 182). To put it differently, these changes are treated as path-following institutional adjustments rather than a deviation from the 
existing path of the denial and suppression of Kurdish identity. The difficulty of such accounts, however, is that the change process is assessed with a teleological view, in the sense that changes are evaluated according to the distance to a desired end point of Kurdish autonomy or independence. However, a better approach would be to look at the degree of shift from the existing institutional configuration. From this perspective, one would label these changes as 'tremendous progress' on the Kurdish issue, 'a big turning point' in the history of the conflict (Hicks 2001, p. 78, Aydın and Keyman 2004, p. 37, Çelik and Rumelili 2006). Broadcasting in Kurdish by the state TV channel in June 2004, for instance, is quite an impressive development given the fact that, until recent times, the official state position was to deny the very existence of different Muslim ethnic groups in the country (Somer 2005b, p. 596). Therefore these changes mark a significant degree of shift from the strictly homogenous, radical understanding of nationality that was blind towards difference, towards a more plural and liberal understanding. To put it in more theoretical terms, these changes mark a shift to a new institutional logic. Evidence from elite interviews also supports this observation. For instance, Selahattin Demirtaş, the chairperson of the Human Rights Association (Diyarbakır Branch), stated to the author that:

In the twenty-first century, these changes remain limited . . . However we can not evaluate these changes without considering historical and contextual factors. These changes took place in a country which has argued till recent times that there was no Kurd in the country. Since 1999, these debates have ended. In the 80 year history of the Republic, for the first time, the Turkish state acknowledged that there were Kurds in the country. From this perspective, these changes closed an era and opened a new one, in which debates now focus on which cultural rights, on which basis (group or individual) should be given. (Emphasis added.) $)^{7}$

Similarly, in its annual assessment of Turkey's progress towards accession, the European Commission stated that:

Overall, Turkey has made noticeable progress towards meeting the Copenhagen political criteria since the Commission issued its report in 1998, and in particular in the course of the last year [2002]. The reforms adopted in August 2002 are particularly far-reaching. Taken together, these reforms provide much of the ground work for strengthening democracy and the protection of human rights in Turkey. ${ }^{8}$

In brief, despite difficulties and problems with their implementation, these changes mark a substantial shift from denial and suppression to the acknowledgement of the existence of different Muslim ethnic identities and of the necessity of granting certain cultural rights to these groups. Therefore, they represent a path-breaking development in Turkey's Kurdish issue.

\section{Explaining the initiation of the change process}

How did this change process start? What were the main trigger and mechanisms? Why did these changes take place at the beginning of the 2000s, but not before? A widely shared suggestion in the existing literature on recent reforms in Turkey states that the main trigger for this change process was the European Union's (EU) recognition of Turkey as a candidate state for membership at the Helsinki Summit in 1999 (Öniş 2003, p. 13, Zucconi 2003, Magen 2003, p. 32, Aydın and Keyman 2004, p. 15, Kubicek 2005, p. 361). The question still to be answered, however, is why the EU trigger successfully initiated the process whilst other events had not. A strong theoretical account of this change process 
requires a satisfactory response to this important question. Some internal and external developments that had strong potential for initiating such a change process at an earlier period were: the post-Cold War democratization process, the Gulf War (1990-1) and the rise of Kurdish ethno-nationalism in the 1990s.

\section{Post-Cold War democratization}

The end of the Cold War was a major structural event in the international system in the late twentieth century. One important consequence of this major event was to reveal prospects for democratization in several parts of the world (Lewis 1997, p. 393). The political and economic support by Western and Soviet blocs for authoritarian and repressive regimes in the Third World declined in the post-Cold War era. Soviet control in Central and Eastern European countries also ended. All of these developments promoted democratization movements across the world. According to one estimate based on the reversed Freedom House Political Rights Index, the average democracy score was 3.99 in 79 countries for the 1981-90 period. This increased to 4.36 in the 1993-6 period, representing a certain degree of democratization (Cingranelli and Richards 1999, p. 521). Post-Cold War democratization, however, was much stronger in Central and Eastern Europe. By the mid1990s, several liberal and partial democracies were established in Eastern Europe. These countries experienced a massive transformation with a goal of setting up new economic and political systems à la Western models (Kaldor and Vejvoda 1999, Berglund et al. 2001). One could easily have expected that this widespread post-Cold War democratization process in the region would have generated a similar impact on the Turkish political system in the 1990s.

\section{The Gulf War (1990-91)}

Another relevant factor was the Gulf War. As Barkey (1996, p. 67) rightly observes, 'the Gulf War and the ensuing Kurdish drama in Iraq, which had hundreds of thousands of Kurds fleeing Saddam's revenge in the aftermath of their ill-fated rebellion, focused the attention of the world, including Turkey - one of the two destinations for these refugees on the unresolved nature of the Kurdish issue in the Middle East'. It could have been expected that this increased level of attention to the Kurdish issue would have created some pressure on Turkey to liberalize its Kurdish policy.

\section{The rise of Kurdish ethno-nationalism in the 1990s}

The suppression and denial of the Kurdish identity has led to several reactionary movements in Turkey since the establishment of the Republic. During the 1920s and 1930s, the young Republic was challenged by many Kurdish uprisings with strong ethno-religious elements. ${ }^{9}$ In the 1990 s, however, the Kurdish nationalist movement, led by the PKK (Partiya Karkaren Kurdistan [Kurdistan Workers Party] established in 1978), became more ethno-nationalist, more organized, more challenging, and also much more violent. The first armed conflict between security forces and Kurdish separatists took place in the early 1980s and its intensity increased in the mid-1990s. From 1984 to 1999, the number of people killed was estimated to be around 30,000 (half of them PKK members, onequarter civilians and one-quarter security members).

Moreover, several pro-Kurdish parties emerged in the 1990s such as Halkın Emek Partisi (People's Labor Party, HEP), 1990-3, Demokrasi Partisi (Democracy Party, 
DEP) 1993-4, and Halkın Demokrasi Partisi (Democracy Party of the People, HADEP), 1994-2003. These parties were typical issue-oriented parties in the sense that their primary concern was the rights and freedoms of Kurds. In general, they advocated that the Kurdish problem could not be limited to a terrorism problem. There was an urgent necessity for a political solution such as granting minority status or cultural rights to Kurds, ending the state of emergency in southeastern Turkey and granting an amnesty to PKK members (Gürbey 1996, pp. 26-8). These parties, however, were accused of separatist activities and propaganda against the indivisible unity of the state's people and its territory and of helping the PKK terrorist organization. As a result they were banned by the Constitutional Court. However, these pro-Kurdish parties became important elements of the Kurdish nationalist movement in the 1990s. In brief, the rise of Kurdish ethno-nationalism and PKK violence in the 1990s formed a strong endogenous shock to the whole system, which led to significant political, social, economic and human costs. ${ }^{10}$ Such a shock had significant potential for initiating some changes in the Turkish state's attitude vis-à-vis the Kurdish issue.

What was the impact of all these endogenous and exogenous events or triggers on Turkey's Kurdish issue? Although there were some changes in the 1990s, it is quite difficult to interpret them as an indicator of the liberalization of the Turkish position on the Kurdish issue. For instance, in April 1991, the law (Law No 2932) which was enacted in 1983 by the military regime and banned the use of the Kurdish language was repealed. As a result of this change, the use of Kurdish in everyday conversation was allowed but the ban on the use of Kurdish in media (publication and broadcasting) and in education or in public realms such as government institutions or political campaigns remained (Gunter 1997, p. 62, Romano 2006, p. 55). Although some publications emerged in the later period, they were banned or confiscated and several authors and publishers were sentenced to prison terms. This quite limited change was a result of the flow of one and a half million Kurdish refugees from Iraq into Iran and Turkey (Kirişçi and Winrow 1997, p. 113). Although this action created opportunities for the free use of the Kurdish language, the reluctance of Turkish state authorities to allow even free use of Kurdish continued. In the following period, several politicians also acknowledged that there was a Kurdish reality in Turkey. ${ }^{11}$ However, later it became obvious that these statements were primarily just rhetoric used to increase the popularity of the government - especially among the Kurds and/or to increase the prestige of the government abroad rather than marking a real change in the state's attitude vis-à-vis the Kurdish issue.

So, despite such statements by some of the political elite in the $1990 \mathrm{~s}$, this new rhetoric did not represent a genuine shift to a new institutional path, because state resistance to any open demonstration of Kurdish identity continued throughout the 1990s (Watts 1999). Using the words of Somer (2005a, p. 74), 'while Kurdish difference and its distinct identity were increasingly acknowledged [in the period from 1984-98], mainstream beliefs regarding the desirability or acceptability of any Kurdish ethnic-cultural and political rights and expressions did not necessarily change' (also see Gürbey 2000, p. 64, Somer $2005 \mathrm{~b}$, p. 614). The state continued to view the issue primarily as a matter of socioeconomic underdevelopment, security and terrorism rather than as a political or ethnic problem (Bozarslan 1996, p. 17). As a result, any calls for the recognition of Kurdish identity and cultural rights were treated as a separatist, terrorist act, which should be suppressed with severity.

Figure 2 also confirms that, despite the existence of certain triggers, there was not much change in the level of political and civil rights in Turkey during the 1990s. However, we see significant improvements in the post-Helsinki era (1999 onwards). This analysis clearly 


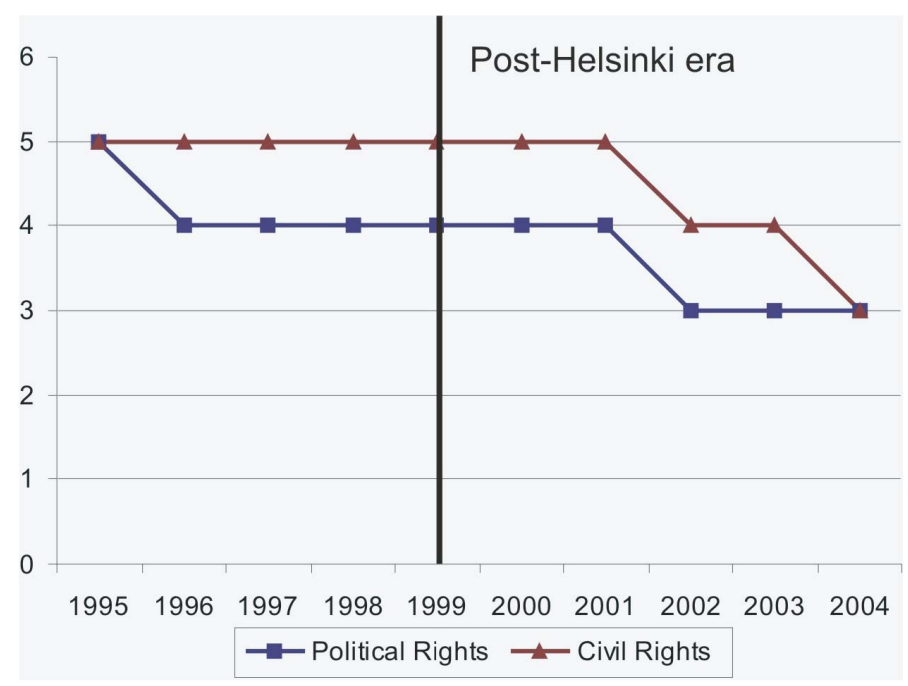

Figure 2. The level of political and civil rights in Turkey (1995-2004).

Note: Lower numbers represent more rights and freedoms.

Source: Freedom in the World, 2005 (Freedom House). Available from: http://www.freedomhouse. org/template.cfm?page=363\&year=2005 [Accessed 6 April 2006].

shows that the Turkish political system was not really responsive to the internal or external triggers in the 1990s, but was much more responsive to the EU trigger in the early $2000 \mathrm{~s}$.

As indicated above, in order to understand the reasons for why institutions are much more responsive to certain triggers than others, we should pay more attention to the meanings of those triggers for institutional actors, in particular for change agents. From this perspective, the EU trigger played a substantial role in the recent changes because joining the EU means finalizing Turkey's century old modernization project, which should be read as Westernization (Akman 2004, p. 39), and thus being recognized as a Western state in the international community. Therefore, EU membership has been one of the most important foreign policy objectives of the Turkish Republic (Ergil 2000, p. 123, Zucconi 2003, p. 17).

Just to briefly mention the origins of pro-Western orientation in the Republic, Westernization efforts started in the late Ottoman period. After realizing the military superiority of Europe in the early 1800s, the Ottomans first began to modernize their army. Thus, the initial motivation for the reforms was to re-establish military equivalence with the European powers (Lewis 1979, p. 84, Rustow 1981, p. 59, Ahmad 1993, p. 22, Karaosmanoğlu 1994, p. 118, Akman 2004, p. 34). In the later periods of the nineteenth century, the Ottomans continued reform efforts and embraced certain parts of the European administrative system, arts and sciences, law and education (Allen 1968, Karal 1981, p. 24, Rustow 1981, p. 59). ${ }^{12}$ In other words, the reference point for the Ottoman reform efforts was simply European civilization. Modernization was simply understood as 'borrowing from the West' (Heper 2005, p. 34).

The Republican reforms of the 1920s and 1930s under the leadership of Kemal Atatürk intensified, radicalized and culminated in this trend of modernization as Westernization process (Özbudun and Kazancigil 1981, p. 3). As indicated above, the ultimate goal of the Kemalist mentality or vision was to set up a modern, secular and centralized nation state. Kemalist thought defined modernization in terms of Westernization (i.e. the 
adoption of complete Western civilianization, understandings and practices) (Karal 1981, pp. 12-13, 31-2, Rustow 1981, pp. 59-60, Oran 2005, p. 112). Since its initiation, this ideal of modernization as Westernization has been a strong constitutive element of the Turkish Republic. In the second half of the twentieth century, this ideal meant joining the European Economic Community/ European Union. Thus, the recognition of Turkey as a candidate state for the EU in 1999, which symbolizes European unity and civilization, was perceived as an important step in Turkey's march toward the West.

This can be clearly seen in the bargaining process over the Third Harmonizing Package (August 2002), which was passed by a highly fragile and divided coalition government composed of the nationalist center left party, Demokratik Sol Partisi (Democratic Left Party, DSP), the ultranationalist right party, Milliyetçi Hareket Partisi (Nationalist Action Party, MHP) and the liberal, center right party, Anavatan Partisi (Motherland Party, ANAP). The MHP strongly opposed the suggested changes. The party believed that the package would threaten state security and national unity and would reward terrorism and separatism. As a result, the party attempted to delegitimize the reform package by using security related frames such as 'rewarding terrorists', 'endangering national unity, state security' etc. For instance, Bozkurt Yaşar Öztürk, an MP from the MHP, stated that: 'We won't let those terrorists left in the mountains come down to the city and participate in (language) courses. Rather than putting out a fire, we are making it bigger'. ${ }^{13}$ İsmail Köse, another MHP deputy, stated that 'In Turkey, there is only one nation, one state and one language ... These proposed changes would threaten our unity, our oneness by leading to divisions in this country ... Eventually, these changes would also lead to the creation of new minorities in the country ... Therefore, if you support these reforms, you will only serve the interests of the terrorist organization' ${ }^{14}$ In brief, the pro-status quo ultra-nationalist MHP tried to securitize EU demands in order to legitimize its opposition to the proposed changes. In other words, the MHP construed the EU trigger and its demands related to cultural rights as a matter of state survival, national unity.

Although the pro-EU, conservative right ANAP was the smallest partner in the coalition government, the party assumed a leadership role in pushing for reforms (Öniş 2003, pp. 17-18). In other words, the party acted as a change entrepreneur and strongly defended the reform package. During parliamentary debates, the party leader Mesut Yilmaz stated that:

Turkey's accession to the EU is the final stage of our two centuries old Westernization efforts ... We already decided to take our place in Western civilization ... And all our efforts to change our state and society in every sense have aimed at being part of this civilization ... We can not give up this ideal at this stage ... Joining the EU is not a party policy but a state ideal, a project above politics . . . Thus we have to realize those things that this ideal requires from us ... By passing these laws we will also prove the strength of Turkish democracy to the whole world ... [emphasis added $]^{15}$

The position of the DSP fell somewhere between the reluctant MHP and the enthusiastic ANAP, but certainly closer to the ANAP. Similarly to the ANAP, the party has usually been supportive of Turkey's cultural, political and economic relations with the West (Güneş-Ayata 2003, p. 215, Başkan 2005, p. 61). During parliamentary debates, Masum Türker expressed the party's support for the harmonizing package in the following way: We consider Turkey's EU membership as a state goal, an issue above politics. These changes will not only get us closer to this ideal but also dramatically empower Turkish democracy. With these changes, Turkey will gain a significant degree of prestige in the world. In the end, the MHP voted 'No' en bloc but the reform package was passed by the 
parliament as a result of the yes votes of deputies from the other two member parties of the government and from the opposition parties.

These parliamentary debates, however, indicate that exogenous or endogenous triggers or shocks may be interpreted or constructed quite differently by different institutional actors. In our case, several actors interpreted and framed the EU's recognition of Turkey as a candidate state for membership as a rather important development in Turkey's Westernization process. As a result, they argued that the proposed changes would help Turkey integrate with the West, the ultimate objective of Turkey's long-term modernization efforts. Moreover, the EU trigger was also interpreted as an important opportunity for further economic progress in the country. Various domestic actors expected that Turkey's accession to the EU would bring significant economic and security gains. On the other hand, pro-status quo actors (e.g. the ultranationalist MHP) framed the whole process as a matter of national security rather than further democratization or Westernization. The winners of these framing contests were pro-change actors because the MHP was one of the few domestic actors approaching the issue from purely a national security standpoint. Furthermore, the security-oriented framings failed or remained less effective than the democratization, Westernization framings because they were much more resonant at that time. In other words, pro-change actors' frames were more credible due to the relatively better fit between the framings and the general trend in domestic politics.

This analysis indicates that change entrepreneurs are more likely to be mobilized by those triggers which are directly or indirectly related to the predominant ideals and values in an institutional environment. This is because change agents know that they can better convince the status-quo-oriented or neutral actors and the audience about the necessity of structural changes by framing them in terms of those broader ideals and values. ANAP's framing of the Third Harmonizing Package, which brought about substantial changes in a quite sensitive and controversial issue in Turkish politics, as an important step in line with Turkey's long-term Westernization ideal, is a rather good illustration of this.

In brief, although the Turkish political system encountered several triggers in the 1990 s, the system did not respond to those triggers or perturbations in the same way as it did to a different trigger in the early 2000s. As indicated above, pro-Kurdish political parties and the PKK, as important elements of the Kurdish ethno-nationalist movement in the 1990s, articulated similar demands (i.e. granting cultural rights to Kurds), but we did not see path-breaking changes in the 1990s. However, the EU trigger was much more successful in initiating significant changes in Turkey's Kurdish issue because pro-change agents successfully took advantage of the fit between the trigger and the long-term Westernization ideal in Turkey. At this point, one might still ask the question why change was triggered around adhesion to the EU in the early 2000s when Turkish-EU relations date back to the early 1960s. For instance, Turkey has been an associate member of the European Union and its precursors since 1963 . Why, then, did this factor suddenly produce more endogenous effects at the turn of this century? The simple answer to this question is that by officially recognizing Turkey as a candidate state for EU membership during the 1999 Helsinki Summit, the EU leaders sent a very strong and credible signal to domestic actors about possible membership for the first time in the history of Turkish-EU relations. As a result, domestic actors became more optimistic about Turkey's accession to the EU in the near future. This, in turn, led to the formation of broad and strong domestic support for Turkey's EU membership and for EU reforms at that time (almost 70\%). This created a rather favorable environment for change agents to promote major changes in a sensitive area in the early 2000 s. 


\section{Conclusion}

The Turkish Republic has achieved major constitutional, legislative and institutional changes across various issue or policy areas in the last five to six years. Observers in the media and within academic circles treat this comprehensive reform process as a momentous shift (Magen 2003, p. 31); revolutionary (Oran 2005, p. 112); unthinkable (Kubicek 2005, p. 362); profound (Öniş 2003, p. 13); impressive (Aydın and Keyman 2004, p. 1); and unprecedented (Moustakis and Chaudhuri 2005). It was shown that the EU's recognition of Turkey as a candidate state for membership in 1999, an exogenous development, successfully initiated path-breaking changes in Turkey's Kurdish issue. Alternative triggers such as the post-Cold War democratization process, the Gulf War (1990-1) and the rise of Kurdish ethno-nationalism in the 1990s simply failed to initiate such a change process at an earlier time. The EU trigger was successful because certain ideational and material incentives provided by future EU membership (e.g. a significant step in Turkey's Westernization process and expected economic and security gains) empowered change entrepreneurs in mobilizing support for substantial changes in such a sensitive area.

With respect to the implications of this analysis, as indicated above, institutionalist orientations relying on exogenous deus ex machina to explain path-breaking changes do not tell us much about the timing, direction or mechanisms of the change process. This study shows that exogenous developments or shocks do not lead to new paths by operating in the fashion of deus ex machinas. Rather, institutional actors are selective in their responses to those developments. Understanding this variance requires a more dynamic notion of agency, because actors' interpretations, constructions or framings of those events matter much more than those developments' themselves. As Colomy (1998, p. 293) convincingly suggests:

\footnotetext{
... alterations in the institutional order cannot be fully understood without attending to the projects, interests, mobilizing efforts, and strategies of concrete actors, groups, and organizations ... Entrepreneurs, acting not as the selfless agents of systemic exigencies or institutionalized myths but in pursuit of a project advancing their particular ideal and material interests, play a vital role in determining the specific contours, content, and character of those structures that become institutionalized, however, imperfectly.
}

As the above analyses indicate, a certain trigger might be constructed or framed rather differently by different actors in an institutionalized setting. Change agents (e.g. ANAP) in particular reconstruct external or internal triggers in such a way as to advance their particular interests. While doing this they also deconstruct the existing institutional structures to legitimize their proposals for institutional change. Pro-status quo actors (e.g. MHP), on the other hand, develop counter framings to delegitimize those efforts. Within these framing contests, triggers which might be linked to existing broader predominant ideals and values enhance the effectiveness of pro-change framings. All these suggest that human agency in the institutional world is not necessarily a passive figure led by institutional paths and routines or by a deus ex machina, but a creative, innovative actor leading those paths to new directions and forms and responding creatively to external and/or internal developments. In other words, institutional actors are not merely 'path takers' but also 'path shapers'. Therefore, it would not be an exaggeration to propose that paths are actually what actors make of them!

\section{Acknowledgements}

Earlier versions of this article were presented at the Midwest Political Science Association $65^{\text {th }}$ Annual National Conference, 12-15 April 2007, Chicago-IL and at the Workshop on "New Developments in the Field of Historical Institutionalism", Roskilde University, Denmark, 9 April 
2008. I would like to thank Stacy Bondanella, Peter Hall, Martin Marcussen, Erin McGrath, B. Guy Peters, Jacob Torfing, the editor and reviewers for very helpful comments and suggestions on the earlier versions of this work.

\section{Notes}

1. Such discontinuous change is also known as punctuated equilibrium, which originated from debates in biology (Campbell 2004, p. 24).

2. For an example of path-breaking change which results from the interrelation of endogenous and exogenous factors, see Ruane and Todd (2007).

3. The same argument would also hold for the second approach, which attributes the source of institutional change to endogenous developments.

4. For more on Turkey's Kurdish issue see Entessar (1992), McDowall (1996), Olson (1996), Kirişçi and Winrow (1997), Gunter (1997) and Robins (2000).

5. The Turkish Daily News defined this reform package as a 'landmark event' (3 August 2002). For the Financial Times, the reform was a 'watershed', 'the dawn of a new era' in Turkey (5 August 2002).

6. In January 2009, TRT 6 was launched, which was another significant development in the Kurdish issue. TRT 6 is Turkey's first national Kurdish language television station which broadcasts in the Kurmanji, Sorani and Zaza dialects.

7. Author's interview, July 2006, Diyarbakır. Yusuf Alataş, the Chairperson of the pro-change, pro-Kurdish Human Rights Association (IHD) and Edip Polat, the Chairperson of the Kurdish Writers Association, also expressed similar views. Interviews were conducted in June 2006, in Ankara; and in July 2006, in Diyarbakır, respectively.

8. European Commission, 2002 'Regular Report on Turkey's Progress towards Accession. Brussels,' 9 October 2002, SEC(2002) 1412, p. 46.

9. In the period 1924-38, there were 18 uprisings in Turkey. Seventeen of them took place in eastern Anatolia and 16 of them involved Kurds (Kirişçi and Winrow 1997, p. 100).

10. Other than its human costs, this conflict also led to an economic cost of $\$ 100$ billion (Yetkin 2005).

11. In December 1991, the then Prime Minister Süleyman Demirel used this expression during his visit to Diyarbakır.

12. For a comprehensive historical analysis of the Ottoman reform efforts see Lewis (1979), pages $75-129$.

13. Turkey abolishes death penalty. $C N N, 3$ August 2002. Available from: http://archives.cnn.com/ 2002/WORLD/meast/08/03/turkey.death.pen/index.html [Accessed 25 December 2006].

14. TBMM, Genel Kurul Tutanağı, 21. Dönem, 4. Yasama Yll, 124. Birleşim, 1 Ağustos 2002 [The record of parliamentary debates, 1 August 2002]. Available from: http://www.tbmm.gov.tr [Accessed 25 December 2006].

15. Ibid.

\section{Notes on contributor}

Zeki Sarigil is an assistant professor at the Department of Political Science, Bilkent University. His research interests include institutional theory, institutional change, civil-military relations, ethnonationalism, and international relations. He has published articles in Mediterranean Politics and Armed Forces \& Society, and has forthcoming articles in the European Journal of International Relations and Ethnic and Racial Studies.

\section{References}

Ahmad, F., 1993. The making of modern Turkey. London and New York: Routledge.

Akman, A., 2004. Modernist nationalism: statism and national identity in Turkey. Nationalist papers, 32 (1), 23-51.

Akyol, M., 2006. Kürt Sorununu Yeniden Düşünmek: Yanlış Giden Neydi? Bundan Sonra Nereye? [Rethinking Kurdish problem: what went wrong, and where to go from here?]. Istanbul: Doğan Kitapçılık. 
Alexander, G., 2001. Institutions, path dependence, and democratic consolidation. Journal of theoretical politics, 13 (3), 249-270.

Allen, H.E., 1968. The Turkish transformation: a study in social and religious development. New York: Greenwood Press.

Arthur, W.B., 1994. Increasing returns and path dependence in the economy. Ann Arbor: University of Michigan Press.

Aydın, S., and Keyman, E.F., 2004. European integration and the transformation of Turkish democracy. EU-Turkey working papers, no. 2.

Barkey, H.J., 1996. Under the gun: Turkish foreign policy and the Kurdish question. In: R. Olson, ed. The Kurdish nationalist movement in the 1990s: its impact on Turkey and the Middle East. Kentucky: University Press of Kentucky, 65-84.

Barkey, H.J., and Fuller, G.E., 1997. Turkey's Kurdish question: Critical turning points and missed opportunities. Middle East journal, 51 (1), 59-79.

Başkan, F., 2005. At the crossroads of ideological divides: cooperation between leftists and ultranationalists in Turkey. Turkish studies, 6 (1), 53-69.

Baumgartner, F.R., and Jones, B.D., 1991. Agenda dynamics and policy subsystems, The journal of politics, 53 (4), 1044-1074.

Beckert, J., 1999. Agency, entrepreneurs, and institutional change. The role of strategic choice and institutionalized practices in organizations. Organization studies, 20 (5), 777-799.

Berglund, S., Aarebrot F.H., Vogt, H., and Karasimeonov, G., 2001. Challenges to democracy: Eastern Europe ten years after the collapse of communism. Cheltenham and Northampton: Edward Elgar.

Blyth, M., 2002. Great transformations: economic ideas and institutional change in the twentieth century. Cambridge: Cambridge University Press.

Bozarslan, H., 1996. Turkey's elections and the Kurds. Middle East report, 199 (Apr-Jun), 16-19.

Braude, B., and Lewis, B., 1982. Christians and Jews in the Ottoman Empire: 1-2. New York: Holmes \& Meier Publishers Inc.

Bruinessen, M. van, 1978. Agha, Shaikh and state: on the social and political organization of Kurdistan. Utrecht: University of Utrecht.

Campbell, J.L., 2004. Institutional change and globalization. Princeton and Oxford: Princeton University Press.

Carey, J.M., 2000. Parchment, equilibria, and institutions. Comparative political studies, 33 (6), 735-761.

Carter, C.A., 2008. Identifying causality in public institutional change: the adaptation of the National Assembly for Wales to the European Union. Public administration, 86 (2), 345-361.

Çelik, A.B., and Rumelili, B., 2006. Necessary but not sufficient: the role of the EU in resolving Turkey's Kurdish question and the Greek-Turkish conflicts. European foreign affairs review, $11(2), 203-222$.

Cingranelli, D.L., and Richards, D.L., 1999. Respect for human rights after the end of the Cold War. Journal of peace research, 36 (5), 511-534.

Collier, R.B., and Collier, D., 1991. Shaping the political arena: critical junctures, the labor movement and regime dynamics in Latin America. Princeton: Princeton University Press.

Colomy, P., 1998. Neofunctionalism and neoinstitutionalism: human agency and interest in institutional change. Sociological forum, 13 (2), 265-300.

Crouch, C., and Farrell, H., 2004. Breaking the path of institutional development? Alternatives to the new determinism. Rationality and society, 16 (1), 5-43.

Crouch, C., and Keune, M., 2005. Changing dominant practice: making use of institutional diversity in Hungary and the United Kingdom. In: W. Streeck and K. Thelen, eds. Beyond continuity: institutional change in advanced political economies. Oxford: Oxford University Press, 83-102.

Deeg, R., 2005. Change from within: German and Italian finance in the 1990s. In: W. Streeck and K. Thelen, eds. Beyond continuity: institutional change in advanced political economies. Oxford: Oxford University Press, 169-202.

Dees, J.G., 1998. The meaning of 'social entrepreneurship'. Available from: http:// www.fntc.info/files/documents/The\%20meaning\%20of\%20Social\%20Entreneurship.pdf [Accessed 13 August 2007]

Dimitrakopoulos, D.G., 2001. Incrementalism and path dependence: European integration and institutional change in national parliaments. Journal of common market studies, 39 (3), 405-422.

Eisenstadt, S.N., 1964. Institutionalization and change. American sociological review, 29 (2), 235-247.

Emirbayer, M., and Mische, A., 1998. What is agency? The American journal of sociology, 103 (4), $962-1023$. 
Entessar, N., 1992. Kurdish ethnonationalism. Boulder, CO: Lynne Rienner.

Ergil, D., 2000. The Kurdish question in Turkey. Journal of democracy, 11 (3), 122-135.

European Commission, 1998. Regular report 1998, from the Commission on Turkey's progress towards accession. Brussels: Commission of the European Community.

Gains, F., John, P.C., and Stoker, G., 2005. Path dependency and the reform of English local government. Public administration, 83 (1), 25-45.

Genschel, P., 1997. The dynamics of inertia: institutional persistence and change in telecommunications and health care. Governance: an international journal of policy and administration, 10 (1), 43-66.

Göle, N., 1997. The quest for the Islamic self in the context of modernity. In: S. Bozdoğan and R. Kasaba, eds. Rethinking modernity and national identity in Turkey. Seattle and London: University of Washington Press.

Greener, I., 2005. State of the art: the potential of path dependence in political studies. Politics, 25 (1), 62-72.

Greif, A., and Laitin, D.D., 2004. Theory of institutional change. American political science review, 98 (4), 633-652.

Güneş-Ayata, A., 2003. From Euro-scepticism to Turkey-scepticism: changing political attitudes on the European Union in Turkey. Journal of Southern Europe and the Balkans, 5 (2), 205-222.

Gunter, M.M., 1990. The Kurds in Turkey: a political dilemma. Boulder, San Francisco and Oxford: Westview Press.

Gunter, M.M., 1997. The Kurds and the future of Turkey. New York: Saint Martin's Press.

Gürbey, G., 1996. The Kurdish nationalist movement in Turkey since the 1980s. In: R. Olson, ed. The Kurdish nationalist movement in the 1990s: its impact on Turkey and the Middle East. Kentucky: University Press of Kentucky, 9-38.

Gürbey, G., 2000. Peaceful settlement of Turkey's Kurdish conflict through autonomy. In: F. İbrahim and G. Gürbey, eds. The Kurdish conflict in Turkey: obstacles and chances for peace and democracy. New York: Saint Martin's Press, 57-91.

Hall, P.A., and Taylor, R.C.R., 1996. Political science and the three new institutionalisms. Political studies, 44 (4), 936-957.

Harty, S., 2005. Theorizing institutional change. In: A. Lecours, ed. New institutionalism: theory and analysis. Toronto: University of Toronto, 51-80.

Hay, C., and Wincott, D. 1998. Structure, agency and historical institutionalism. Political studies, $46(5), 951-957$.

Helmke, G., and Levitsky, S., 2004. Informal institutions and comparative politics: a research agenda. Perspectives on politics, 2 (4), 725-740.

Hemerijck, A.C., 1995. Corporatist immobility in the Netherlands. In: C. Crouch and F. Traxler, eds. Organized industrial relations in Europe: what future? Aldershot and Brookfield: Avebury, 183-226.

Heper, M., 2005. The European Union, the Turkish military and democracy. South European society and politics, 10 (1), 33-44.

Héritier, A., 2007. Explaining institutional change in Europe. New York: Oxford University Press.

Hicks, N., 2001. Legislative reform in Turkey and European human rights mechanisms. Human rights review, 3 (1), 78-85.

Homans, G.C., 1964. Bringing men back in. American sociological review, 29 (5), 809-818.

Ikenberry, G.J., 1989. Conclusion: an institutionalist approach to American foreign economic policy. In: G.J. Ikenberry, D.A. Lake and M. Mastanduno, eds. The State and American foreign economic policy. Ithaca, NY: Cornell University Press, 219-235.

Kaldor, M., and Vejvoda, I., eds, 1999. Democratization in Central and Eastern Europe. London and New York: Pinter.

Karal, E.Z., 1981. The principles of Kemalism. In: A. Kazancigil and E. Özbudun, eds. Atatürk: founder of a modern state. Hamden, CT: Archon Books, 11-35.

Karaosmanoğlu, A.L., 1994. The limits of international influence for democratization. In: M. Heper and A. Evin, eds. Politics in the Third Turkish Republic. Boulder, San Francisco and Oxford: Westview Press.

Kasaba, R., and Bozdoğan, S., 2000. Turkey at a crossroad. Journal of international affairs, 54 (1), 1-20.

Kirişçi, K., and Winrow, G.M., 1997. The Kurdish question and Turkey: an example of a trans-state ethnic conflict. Portland, OR: Frank Cass.

Knight, J., 1992. Institutions and social conflict, Cambridge: Cambridge University Press.

Kramer, H., 2000. A changing Turkey: the challenge to Europe and the United States. Washington, DC: Brookings Institution Press. 
Krasner, S., 1984. Approaches to the state: alternative conceptions and historical dynamics. Comparative politics, 16 (2), 223-246.

Kubicek, P., 2005. The European Union and grassroots democratization in Turkey. Turkish studies, $6(3), 361-377$.

Kymlicka, W., 1995. Misunderstanding nationalism. Dissent, 42 (1), 130-137.

Legro, J.W., 2000. The transformation of policy ideas. American journal of political science, 44 (3), $419-432$.

Levi, M., 1990. A logic of institutional change. In: K. Schweers Cook and M. Levi, eds. The limits of rationality. Chicago: University of Chicago Press, 402-418.

Levi, M., 1997. A model, a method, and a map: rational choice in comparative and historical analysis. In: M.I. Lichbach and A.S. Zuckerman, eds. Comparative politics: rationality, culture and structure. Cambridge: Cambridge University Press, 19-41.

Lewis, B., 1979. The emergence of modern Turkey. 2nd ed. Oxford: Oxford University Press.

Lewis, P., 1997. Democratization in Eastern Europe. In: D. Potter, D. Goldblatt, M. Kiloh and P. Lewis, eds. Democratization. Cambridge: Polity Press/ The Open University, 393-421.

Liebowitz, S.J., and Margolis S.E., 1999. Path dependence. Available from: http://encyclo.findlaw.com/0770book.pdf [Accessed 2 February 2009].

Magen, A.A., 2003. EU membership conditionality and democratization in Turkey: the abolition of the death penalty as a case study. Master Thesis, Stanford Law School, J.S.M. (SPILS). Available from: http://law-stage.stanford.edu/publications/dissertations_theses/diss/MagenAmichai2003.pdf [Accessed 22 January 2007].

Mahoney, J., 2000. Path dependence in historical sociology. Theory and society, 29 (4), 507-548.

Mahoney, J., 2001. Path-dependent explanations of regime change: Central America in comparative perspective. Studies in comparative international development, 36 (1), 111-141.

Mahoney, J., and Goertz, G., 2004. The possibility principle: choosing negative cases in comparative research. American political science review, 98 (4), 653-669.

McDowall, D., 1996. A modern history of the Kurds. London: I.B. Tauris.

Mintrom, M., 1997. Policy entrepreneurs and the diffusion of innovation. American journal of political science, 41 (3), 738-770.

Mintrom, M., and Vergari, S., 1996. Advocacy coalitions, policy entrepreneurs, and policy change. Policy studies journal, 24 (3), 420-434.

Moustakis, F., and Chaudhuri, R., 2005. Turkish-Kurdish relations and the European Union: an unprecedented shift in the Kemalist paradigm. Mediterranean quarterly, 16 (4), 77-89.

Nohrstedt, D., 2008. The politics of crisis policymaking: Chernobyl and Swedish nuclear energy policy. The policy studies journal, 36 (2), 257-278.

Olsen, J.P., 2009. Change and continuity: an institutional approach to institutions of democratic government. European political science review, 1 (1), 3-32.

Olson, R., ed., 1996. The Kurdish nationalist movement in the 1990s: its impact on Turkey and the Middle East. Kentucky: The University of Kentucky Press.

Öniş, Z., 2003. Domestic politics, international norms and challenges to the state: Turkey-EU relations in the post-Helsinki era. Turkish studies, 4 (1), 9-34.

Oran, B., 2005. Türkiye'de Azınlıklar: Kavramlar, Teori, Lozan, İç Mevzuat, İçtihat, Uygulam [Minorities in Turkey: concepts, theory, Lozan, domestic law and application]. Istanbul: İletişim.

Özbudun, E., 2000. Contemporary Turkish politics: challenges to democratic consolidation. Boulder and London: Lynne Rienner Publishers.

Özbudun, E., and Kazancigil, A., 1981. Introduction. In: A. Kazancigil and E. Özbudun, eds. Atatürk: founder of a modern state. Hamden, CT: Archon Books, 1-11.

Pempel, T.J., 1998. Regime shift: comparative dynamics of the Japanese political economy. Ithaca, NY: Cornell University Press.

Peters, B.G., 1999. Institutional theory in political science: the new institutionalism. London and New York: Pinter.

Peters, B.G., Pierre, J., and King, D.S., 2005. The politics of path dependency: political conflict in historical institutionalism. The journal of politics, 67 (4), 1275-1300.

Pierson, P., 2000a. The limits of design: explaining institutional origins and change. Governance: an international journal of policy and administration, 13 (4), 475-499.

Pierson, P., 2000b. Increasing returns, path dependence, and the study of politics. The American political science review, 94 (2), 251-267. 
Pierson, P., 2004. Politics in time: history, institutions and social analysis. Princeton: Princeton University Press.

Powell, W.W., 1991. Expanding the scope of institutional analysis. In: W.W. Powell and P.J. Dimaggio, eds. The new institutionalism in organizational analysis. Chicago: University of Chicago Press, 183-203.

Robins, P., 2000. Turkey and the Kurds: missing another opportunity? In: M. Abramowitz, ed. Turkey's transformation and American policy. New York: The Century Foundations Press, 61-95.

Romano, D., 2006. The Kurdish nationalist movement: opportunity, mobilization and identity. Cambridge: Cambridge University Press.

Ruane, J., and Todd, J., 2007. Path dependence in settlement processes: explaining settlement in Northern Ireland. Political studies, 55 (2), 442-458.

Rustow, D.A., 1981. Atatürk as an institution-builder. In: A. Kazancigil and E. Özbudun, eds. Atatürk: founder of a modern state. Hamden, CT: Archon Books, 57-77.

Saatçi, M., 2002. Nation-states and ethnic boundaries: modern Turkish identity and TurkishKurdish conflict. Nations and nationalism, 8 (4), 549-564.

Schwartz, H., 2005. Down the wrong path: path dependence, markets and increasing returns. Available from: http://www.people.virginia.edu/ hms2f/ [Accessed 20 November 2005].

Sewell, W.H., 1996. Three temporalities: toward an eventual sociology. In: T.J. McDonald, ed. The historic turn in the human sciences. Ann Arbor: University of Michigan Press, 245-281.

Sheingate, A.D., 2003. Political entrepreneurship, institutional change, and American political development. Studies in American political development, 17 (Fall), 85-203.

Somer, M., 2004. Turkey's Kurdish conflict: changing context, and domestic and regional implications. The Middle East journal, 58 (2), 235-253.

Somer, M., 2005a. Defensive- vs. liberal-nationalist perspectives on diversity and the Kurdish conflict: europeanization, the internal debate, and Türkiyelilik. New perspectives on Turkey, 32, 73-91.

Somer, M., 2005b. Resurgence and remaking of identity: civil beliefs, domestic and external dynamics, and the Turkish mainstream discourse on Kurds. Comparative political studies, 38 (6), 591-622.

Soner, B.A., 2005. Citizenship and the minority question in Turkey. In: E.F. Keyman and A. İçduygu, eds. Citizenship in a global world: European questions and Turkish experiences. London and New York: Routledge, 289-309.

Stacey, J., and Rittberger, B., 2003. Dynamics of formal and informal institutional change in the EU. Journal of European public policy, 10 (6), 858-882.

Streeck, W., and Thelen, K., 2005. Introduction: institutional change in advanced political economies. In: W. Streeck and K. Thelen, eds. Beyond continuity: institutional change in advanced political economies, eds. Oxford: Oxford University Press, 1-40.

Thelen, K., 2004. How institutions evolve: the political economy of skill in Germany, Britain, the United States, and Japan. Cambridge: Cambridge University Press.

Thelen, K., and Steinmo, S., 1992. Historical institutionalism in comparative politics. In: S. Steinmo, K. Thelen and F. Longstreth, eds. Structuring politics: historical institutionalism in comparative perspective. Cambridge: Cambridge University Press, 1-33.

Uğur, M., 2003. Testing times in EU-Turkey relations: the road to Copenhagen and beyond. Journal of Southern Europe and the Balkans, 5 (2), 165-183.

Watts, N.F., 1999. Allies and enemies: pro-Kurdish parties in Turkish politics, 1990-1994. International journal of Middle East studies, 31 (4), 631-656.

Watts, N.F., 2006. Activists in office: pro-Kurdish contentions politics in Turkey. Ethnopolitics, 5 (2), 125-144.

Williams, R.A., 2009. Exogenous shocks in subsystem adjustment and policy change: the credit crunch and Canadian banking regulation. Journal of public policy, 29 (1), 29-53.

Yavuz, H., 2001. Five stages of the construction of Kurdish nationalism in Turkey. Nationalism and ethnic politics, 7 (3), 1-24.

Yetkin, M., 2005. Erdoğan ve Baykal'ın Kürt sorunu tanımı [The Attitude of Erdoğan and Baykal on the Kurdish issue]. Radikal, 23 August. Available from: http://www.radikal.com.tr/ haber.php?haberno=162165 [Accessed 26 November 2007].

Zucconi, M., 2003. Turkey's new politics and the European Union. Ethnobarometer working paper, no. 7, April.

Zucker, L.G., 1988. Where do institutional patterns come from? Organizations as actors in social systems. In: Lynne G. Zucker, ed. Institutional patterns and organizations: culture and environment. Cambridge MA: Ballinger Publishing Company, 23-53. 